\title{
Article/Artigo
}

\section{Quality of essential drugs in tropical countries: evaluation of antimalarial drugs in the Brazilian Health System}

\author{
Qualidade de medicamentos essenciais em países tropicais: avaliação de medicamentos \\ antimaláricos no Sistema de Saúde do Brasil
}

\section{Fernando Henrique Andrade Nogueira ${ }^{1}$, Lígia Maria Moreira-Campos ${ }^{1}$, Roseli La Corte dos Santos ${ }^{2}$ and Gerson Antônio Pianetti ${ }^{1}$}

\begin{abstract}
Introduction: The emergence of drug resistance is one of the main problems concerning malaria treatment. The use of counterfeit and/or substandard antimalarial drugs can contribute to the development of parasite resistance. Thus, the aim of this study was to evaluate the quality of antimalarial drugs distributed in Brazil. Methods: Samples containing chloroquine phosphate, mefloquine hydrochloride, primaquine phosphate, and quinine sulfate tablets were delivered to the Rio de Janeiro central storeroom (CENADI), state storerooms (SS), and Basic Health Units (BHUs) in the north region of Brazil - a total of 10 sample sets. After 5 months of storage, the samples were collected, and in vitro quality control analyses according to official and published methods were performed. Results: Inadequate drug storage conditions were found in two SS and in all $\mathrm{BHUs}$ evaluated. There were no quality deviations found in the chloroquine samples. The quinine samples exhibited weight variation above the allowed limits. The primaquine samples were found to have packaging deficiency. The release of mefloquine in samples from some regions showed a statistically significant difference when compared with the CENADI samples. Conclusions: It is important to periodically evaluate the quality and storage conditions of essential drugs. The quality deviations found with the primaquine and quinine samples are not related to storage conditions and must be addressed urgently. The decreased mefloquine release from tablets is related to formulation problems or influenced by inadequate storage conditions, prompting further investigation. Even with the mentioned problems, the samples would probably not contribute to resistant parasite selection.

Keywords: Malaria. Antimalarial drugs. Brazilian Amazon. Drug storage. Drug stability. Quality control.
\end{abstract}

\section{RESUMO}

Introdução: $\mathrm{O}$ aparecimento de resistência aos medicamentos é um dos maiores problemas do tratamento da malária. O uso de medicamentos falsos e/ ou de má qualidade pode contribuir para o desenvolvimento de resistência no parasita. Este estudo tem por objetivo avaliar a qualidade dos medicamentos antimaláricos distribuídos no Brasil. Métodos: Amostras contendo comprimidos de difosfato de cloroquina, cloridrato de mefloquina, difosfato de primaquina e sulfato de quinina foram enviadas ao almoxarifado central na Cidade do Rio de Janeiro (CENADI), almoxarifados estaduais (SS) e Unidades Básicas de Saúde (UBS) nos estados da região norte do Brasil, totalizando dez amostras. Após cinco meses de armazenamento, as amostras foram coletadas e analisadas segundo métodos oficiais e da literatura. Resultados: Foram encontradas condições inadequadas de armazenamento de medicamentos em duas SS e em todas as UBS avaliadas. Não foram encontrados problemas de qualidade com as amostras de cloroquina. As amostras de quinina apresentaram variação de peso acima dos limites permitidos. Amostras de primaquina foram encontradas com problemas na embalagem. A cedência de mefloquina de comprimidos, em algumas regiões, apresentou diferença estatisticamente significativa quando comparada com a amostra do CENADI. Conclusões: É importante avaliar, periodicamente, a qualidade e as condições de armazenamento de medicamentos essenciais. Desvios de qualidade encontrados com as amostras de primaquina e quinina não estão relacionados às condições de armazenamento e devem ser corrigidos urgentemente. $O$ decréscimo na cedência de mefloquina dos comprimidos está relacionado com a formulação ou foi influenciada por condições de armazenamento inadequadas, necessitando de uma investigação posterior. Apesar dos problemas mencionados, as amostras provavelmente não contribuiriam para a seleção de parasitas resistentes.

Palavras-chaves: Malária. Medicamentos antimaláricos. Amazônia Brasileira. Armazenamento de medicamentos. Estabilidade de medicamentos. Controle de qualidade.

1. Departamento de Produtos Farmacêuticos, Faculdade de Farmácia, Laboratório de Controle de Qualidade de Produtos Farmacêuticos e Cosméticos, Universidade Federal de Minas Gerais, Belo Horizonte, MG. 2. Centro de Ciências Biológicas e da Saúde, Laboratório de Parasitologia, Universidade Federal de Sergipe, São Cristóvão, SE.

Address to: Dr. Fernando Henrique Andrade Nogueira. Dept ${ }^{\circ}$ Produtos Farmacêuticos/FaFar/UFMG Av. Presidente Antônio Carlos 6627, Campus Universitário, Faculdade de Farmácia, Bloco 2/Sala 4029, 31270-901 Belo Horizonte, MG, Brasil.

Phone: 5531 3409-6982; Fax: 5531 3409-6976

e-mail: fhanogueira@gmail.com

Received in $21 / 02 / 2011$

Accepted in 15/04/2011

\section{INTRODUCTION}

The emergence of drug resistance is one of the main problems concerning malaria treatment. The first case of chloroquine-resistant falciparum malaria in Africa and South America was reported almost 50 years $\mathrm{ago}^{1}$, and since then, the worldwide emergence of drug resistance has focused its attention on antimalarial drug quality. Mainly in Africa and Southeast Asia, several studies have been conducted to evaluate the presence of substandard and/or counterfeit essential drugs, including antimalarials ${ }^{2-5}$. Treatment failure can be improperly attributed to drug resistance when the product does not meet the qualitative and quantitative requirements ${ }^{6}$.

The use of counterfeit and/or substandard antiinfective drugs can cause increased morbidity and mortality, adverse effects due to an excessive dose or the presence of potentially toxic active ingredients or pathogenic contaminants, increased health costs, loss of confidence in the health care system and in the drug regulatory authorities, and finally, the selection of resistant parasites with subtherapeutic amounts of active ingredient ${ }^{7}$.

In addition to drug quality, the stability of drugs is another issue that should be considered. As malaria is present mainly in tropical regions, antimalarials must be able to remain stable in environments of high temperature and humidity. Studies in Tanzania and Rwanda revealed decreased drug release from chloroquine and quinine tablets after 3 months of storage in simulated tropical conditions: $75 \%$ relative humidity and $40^{\circ} \mathrm{C}^{8-9}$. Submitted to real storage conditions in Burkina Faso, chloroquine tablets exhibited decreased drug content after 450 days $^{10}$. Brazil is classified under region IV of the international climatic zones, which is characterized by high temperature and high humidity ${ }^{11}$, hence the need to evaluate not only the quality but also the stability of drugs.

The Brazilian Public Health System is responsible for the free distribution of antimalarial drugs to patients. Either imported or produced by government manufacturers, the antimalarials are 
stored in the Central de Armazenagem e Distribuição de Insumos Estratégicos (CENADI) in Rio de Janeiro. From there, the drugs are distributed to state storerooms (SS), then to municipalities, and then again to the approximately 3,000 Basic Health Units (BHUs) spread all over the Amazonian region. The BHUs are responsible for thick blood smear microscopic exams and appropriate treatment of patients. The first-choice therapy for Plasmodium vivax infection in Brazil consists of chloroquine and primaquine. Until 2006, quinine, doxycycline, and primaquine were used in the treatment of Plasmodium falciparum infections, and mefloquine and primaquine were preferred for mixed infections ${ }^{12}$. The guideline for the treatment of $P$. falciparum and mixed infections was changed to a combination of artemether and lumefantrine in 2007.

The aim of this study was, thus, to evaluate the quality of antimalarials in the central storeroom (CENADI), in the state storerooms in three Brazilian Amazon states, and additionally, in two locations in each of these same states. Moreover, several parameters of antimalarial drug storage conditions were evaluated to enhance the discussion and to reinforce its importance when evaluating drug quality.

\section{METHODS}

\section{Study design}

Ten sample sets, each containing 100 tablet units of each antimalarial studied, were delivered to 10 different locations, one in the southeast and nine in the north region of Brazil. The packages were labeled, sealed, and placed along with the other antimalarials stored inside the facility. After the 5-month storage period, from June to October 2005, the sample sets were collected, coded, and brought to our laboratory for physical-chemical analysis.

The storage rooms were selected on three levels: the main level in the CENADI, the central storeroom (A), in the southeast region (non-endemic area); the three state storerooms in the north region named $\mathrm{B}_{S S^{\prime}} \mathrm{C}_{\mathrm{sS}}$, and $\mathrm{D}_{\mathrm{ss}}$; and the two BHUs of each state $\left(\mathrm{B}_{1}, \mathrm{~B}_{2}, \mathrm{C}_{1}\right.$, $\mathrm{C}_{2}, \mathrm{D}_{1}$, and $\mathrm{D}_{2}$, respectively). The participating states and locations were omitted to keep their identities confidential. Three parameters were considered in selecting the BHUs: the annual parasitic index (API), the cure verification slides (CVS), and the absence of air-conditioning. The API is the number of malaria cases per 1,000 inhabitants, and it is used to measure the risk of contracting malaria. CVS is the microscopic examination carried out after the end of antimalarial treatment; it is meant to ensure the success of the treatment by confirming the absence of the parasite. The BHUs were selected in areas of middle (API between 10 and 50 positive slides/1,000 inhabitants) or high (API $>50$ positive slides $/ 1,000$ inhabitants) risk for malaria transmission ${ }^{13}$. All the selected BHUs were located in areas where the percentage of CVS was above the state average. Extra packages of antimalarials were left in the BHUs to avoid the utilization of the study samples in case of extreme necessity.

The antimalarials were selected on the basis of their inclusion in the Brazilian National Malaria Control Program at the time of study, their inclusion in the Brazilian National Essential Medicines List, and their common usage. Except for the quinine sulfate tablets, all antimalarials used in this study were from the same batch. The drug samples were (drug, strength, batch number, manufacturing date, expiry date): chloroquine phosphate tablets, $150 \mathrm{mg}$ (as chloroquine), 05030650, Mar/2005, Mar/2007; mefloquine hydrochloride tablets, 250mg (as mefloquine), 0503023, Mar/2005, Mar/2008; primaquine phosphate tablets, $15 \mathrm{mg}$ (as primaquine), 04071297, $\mathrm{Jul} / 2004$, Jul/2006; quinine sulfate tablets, 500mg, 05001022,
Jan/2005; Jan2008; and quinine sulfate tablets, 500mg, 05004103, Apr/2005, Apr/2008. The quinine sulfate tablets from batch 05001022 were stored in regions $\mathrm{A}, \mathrm{B}_{S S}, \mathrm{~B}_{1}, \mathrm{~B}_{2}, \mathrm{D}_{S S}, \mathrm{D}_{1}$, and $\mathrm{D}_{2}$, and those from batch 05004103 were stored in regions $A, C_{S S}, C_{1}$, and $C_{2}$. All the tablets used were produced by government manufacturers.

The dissolution test results of the samples stored in CENADI (A) were compared to those of the samples stored in the Amazonian region (state storerooms and BHUs) using ANOVA followed by Tukey's multiple comparison test. Statistical significance was set at $p<0.05$. The meteorological data for this period were obtained from the Brazilian Instituto Nacional de Meteorologia (INMET) for Rio de Janeiro and the state capitals.

\section{Reference standards}

Chloroquine phosphate, mefloquine hydrochloride, primaquine phosphate, quinine sulfate, quininone, and sulfanilamide reference standards were purchased from the United States Pharmacopeia (Rockville, MD, USA).

\section{Reagents}

The reagents used in HPLC assays were of chromatographic grade, while the others were of analytical grade. Ultra-pure water was obtained from a Milli-QPlus system (Millipore Corporation, Billerica, MA, USA). Chloroform, hydrochloric acid, 1-pentanesulfonate sodium, silver nitrate, sodium nitrite, and sulfuric acid were purchased from Merck (Darmstadt, Germany). Ammonium hydroxide was obtained from Vetec (Duque de Caxias, Brazil). Ethanol, glacial acetic acid, and methanol were purchased from Tedia (Fairfield, $\mathrm{OH}, \mathrm{USA}$ ). Cinchonidine, dihydroquinine, and methanesulfonic acid were purchased from Sigma Aldrich (Milwaukee, WI, USA). Diethylamine was purchased from Spectrum (Gardena, CA, USA).

\section{Equipment}

The HPLC assays were carried out using the Agilent Technologies 1200 series (Palo Alto, CA, USA) equipped with quaternary pump, automatic injector, column oven, and diode array detector. Spectrophotometric analyses were run on a UV 160A spectrophotometer (Shimadzu Corporation, Kyoto, Japan). A DL53 titrator from Mettler Toledo (Greifensee, Switzerland) was used for potentiometric titrations. AnErweka DT 80 dissolution tester (Heusenstamm, Germany) was used in the dissolution tests. A ZT3 disintegration tester, a TB24 hardness tester, and TA3R friability tester from Erweka were used in disintegration, hardness, and friability tests, respectively.

\section{Physical-chemical analysis}

The quality of chloroquine phosphate and quinine sulfate tablets was investigated following their individual monographs in the United States Pharmacopeia $28^{\text {th }}$ edition, USP28-NF23 ${ }^{11}$. The primaquine phosphate tablets were also examined according to the USP28-NF23 individual monograph, except for the uniformity of content, which was adapted from the HPLC method described for the dissolution test.

There is no compendial monograph for mefloquine hydrochloride tablets, and therefore, identification was conducted by comparison of the standard and the sample UV spectra. The identification of chloride was verified by reaction with silver nitrate as described in the Brazilian Pharmacopeia ${ }^{14}$. The dissolution test conditions were obtained from the Pan American Health Organization (PAHO/ OPS). The assay was a modification of the method described by Rao and Murthy in $2002^{15}$. The precision, accuracy, and linearity of the method were confirmed before analysis.

All antimalarial samples were submitted to physical tests of uniformity of weight, hardness, friability, and disintegration as described in the Brazilian Pharmacopeia's general tests and assays ${ }^{14}$. 


\section{RESULTS}

\section{Storage conditions}

The aim of this study was to evaluate the physical-chemical quality of antimalarial drugs; however, a brief comparison of the state storerooms, CENADI storerooms (Table 1), and BHUs (Table 2) is given as an overview of the storage conditions, which can influence drug quality. Several parameters, such as temperature and humidity records, were evaluated in order to assess storage quality.

State $\mathrm{C}$ storeroom $\left(\mathrm{C}_{\mathrm{SS}}\right)$ was the only location that did not keep the sample set during the entire period necessary, allowing the tablets, although segregated, to be distributed as regular medicines. Consequently, physical-chemical analysis was not conducted on this set, and the results presented below refer to only nine locations: CENADI (A), two state storerooms $\left(\mathrm{B}_{\mathrm{SS}}\right.$ and $\left.\mathrm{D}_{\mathrm{SS}}\right)$, and six BHUs $\left(\mathrm{B}_{1}, \mathrm{~B}_{2}, \mathrm{C}_{1}, \mathrm{C}_{2}, \mathrm{D}_{1}\right.$, and $\left.\mathrm{D}_{2}\right)$.

A statistically significant difference was observed when the high temperatures in the capitals of states $\mathrm{B}, \mathrm{C}$, and D were compared with those in Rio de Janeiro (A) (Table 3). The low temperatures in the capitals of states $\mathrm{C}$ and $\mathrm{D}$ were also higher than those in region $\mathrm{A}$. The relative humidity measured in the capital of state $\mathrm{C}$ was higher than that in region $\mathrm{A}$.

\section{Drug samples}

Chloroquine phosphate tablets are packed in paper-polyethylene strips containing 10 tablets each. When the samples were collected, some paper strips were found to be humid, but the inside plastic film kept the tablets intact. The sample from region $\mathrm{D}_{1}$ was stained with a blue liquid, which is probably the Giemsa coloring agent used in blood microscopic exams. Nevertheless, the tablets inside were found to be of normal color and shape. The low relative standard deviation (RSD) obtained with the average of the assay values indicated drug content homogeneity between the samples from the storage rooms in all regions. These assay values are within the acceptance range of $93 \%$ to $107 \%$ of the labeled amount stated by USP $28-N F 23$. When subjected to a dissolution test, all tablets released more than $75 \%$ of chloroquine phosphate in $45 \mathrm{~min}$, in agreement with USP28-NF23 requirements. Six tablets of each sample were tested. The Tukey's comparison test done after ANOVA showed no difference $(p<0.05)$ in average drug release rate between sample $A$ and the other samples.

The mefloquine sample from region $\mathrm{D}_{1}$ was also blue-stained externally; however, the blister package protected the tablets from contamination. The assay method described in the literature for mefloquine hydrochloride in tablets exhibited adequate linearity, accuracy, and precision. All assay values were within the proposed acceptance range, from $90 \%$ to $110 \%$ of the labeled amount. The samples from all regions dissolved more than $75 \%$ of mefloquine hydrochloride. Twelve units from each region were tested. The comparison of averages using Tukey's test after ANOVA showed statistically significant differences between sample $A$ and samples $B_{1}, C_{1}, C_{2}$, and $D_{1}(p<0.05)$.

The primaquine samples from all regions had the aluminum foil of their blister packages detached. This also occurred in the CENADI sample (A). However, the tablets were found to be unchanged.

TABLE 1 - Summary of antimalarial storage conditions in the CENADI (A), and the $B_{s s}, C_{s s}$, and $D_{s s}$ state storerooms.

\begin{tabular}{|c|c|c|c|c|}
\hline Description & $\mathbf{A}$ & $\mathbf{B}_{\text {ss }}$ & $\mathrm{C}_{\mathrm{ss}}$ & $\mathbf{D}_{\mathrm{ss}}$ \\
\hline Air-conditioning & + & + & + & + \\
\hline Drugs protected from direct sunlight & + & + & + & + \\
\hline Stock control system & + & + & + & + \\
\hline Access to drugs allowed to authorized personnel only & + & - & + & + \\
\hline Drugs stored in pallets, distant from floor and walls & + & - & + & + \\
\hline Periodic temperature records & + & - & + & + \\
\hline Record of the places where the antimalarials are distributed & + & - & + & + \\
\hline Presence of a pharmacist & - & - & + & + \\
\hline Antimalarial drug quality control certificates & + & - & + & - \\
\hline Standard operational procedures & + & - & + & - \\
\hline Availability of a distribution control and tracking system for antimalarials & + & - & + & - \\
\hline Periodic relative humidity records & + & - & - & - \\
\hline
\end{tabular}

TABLE 2 - Summary of antimalarial storage conditions in state B, C, and D BHUs.

\begin{tabular}{|c|c|c|c|c|c|c|}
\hline Description & $\mathbf{B}_{1}$ & $\mathbf{B}_{2}$ & $\mathbf{C}_{1}$ & $\mathbf{C}_{2}$ & $\mathbf{D}_{1}$ & $\mathbf{D}_{2}$ \\
\hline Type of construction & $\mathrm{W}$ & M & M & $\mathrm{W}$ & M & $\mathrm{W}$ \\
\hline Patient files & + & + & + & + & + & + \\
\hline Stock control system & + & + & + & + & + & + \\
\hline Drugs stored distant from floor and walls & + & - & + & + & + & + \\
\hline Access to drugs allowed to authorized personnel only & - & + & + & + & - & + \\
\hline Drugs protected from direct sunlight & - & - & + & + & + & + \\
\hline Periodic temperature records & - & - & - & - & - & - \\
\hline Periodic relative humidity records & - & - & - & - & - & - \\
\hline Standard operational procedures & - & - & - & - & - & - \\
\hline
\end{tabular}


TABLE 3 - Meteorological data for Rio de Janeiro (A) and the three state capitals (B, C, and D) during the study period (value \pm standard deviation).

\begin{tabular}{|c|c|c|c|c|c|c|c|c|c|c|c|c|}
\hline \multirow[b]{2}{*}{ Month } & \multicolumn{4}{|c|}{ High temperature $\left({ }^{\circ} \mathrm{C}\right)$} & \multicolumn{4}{|c|}{ Low temperature $\left({ }^{\circ} \mathrm{C}\right)$} & \multicolumn{4}{|c|}{ Relative humidity (\%) } \\
\hline & $\mathrm{A}$ & $\mathrm{B}^{*}$ & $\mathrm{C}^{*}$ & $\mathrm{D}^{*}$ & A & $\mathrm{B}$ & $\mathrm{C}^{*}$ & $\mathrm{D}^{*}$ & $\mathrm{~A}$ & B & $\mathrm{C}^{*}$ & $\mathrm{D}$ \\
\hline June & $29.3 \pm 2.2$ & $\mathrm{~N} / \mathrm{A}$ & $33.0 \pm 1.4$ & $33.0 \pm 0.7$ & $20.1 \pm 1.4$ & $20.8 \pm 0.5$ & $24.0 \pm 0.7$ & $23.5 \pm 0.5$ & $72.3 \pm 6.8$ & $78.0 \pm 4.3$ & $82.5 \pm 6.0$ & $80.3 \pm 3.5$ \\
\hline August & $30.9 \pm 3.5$ & $34.7 \pm 2.3$ & $34.9 \pm 1.2$ & $34.0 \pm 0.7$ & $20.9 \pm 1.7$ & $19.8 \pm 2.6$ & $24.0 \pm 0.8$ & $22.9 \pm 0.6$ & $68.7 \pm 9.0$ & $66.8 \pm 8.5$ & $82.8 \pm 4.1$ & $77.1 \pm 4.4$ \\
\hline September & $26.8 \pm 3.9$ & $33.8 \pm 3.8$ & $35.0 \pm 2.3$ & $33.8 \pm 0.6$ & $19.9 \pm 1.7$ & $20.8 \pm 2.2$ & $24.1 \pm 1.1$ & $22.5 \pm 0.5$ & $76.8 \pm 8.9$ & $71.3 \pm 6.8$ & $84.3 \pm 6.2$ & $77.2 \pm 4.2$ \\
\hline October & $31.2 \pm 4.0$ & $35.1 \pm 1.9$ & $35.2 \pm 1.8$ & $33.7 \pm 0.7$ & $22.9 \pm 2.0$ & $22.6 \pm 0.9$ & $24.5 \pm 1.1$ & $22.7 \pm 0.6$ & $72.9 \pm 7.8$ & $78.2 \pm 6.3$ & $83.0 \pm 5.5$ & $76.8 \pm 6.0$ \\
\hline
\end{tabular}

N/A: data not available, * ${ }^{*}$ statistically significant difference of averages compared with Rio de Janeiro.

USP28-NF23 specifies that the primaquine phosphate content should be $93 \%$ to $107 \%$ of the declared amount, and all samples met this criterion. Dissolution tests were performed on six tablets from each region. The drug release rate was in agreement with USP28NF23 requirements, more than $80 \%$ of primaquine phosphate in 60 min. No statistically significant difference $(p<0.05)$ in drug release between sample A and the other samples was observed.

In the test of uniformity of weight for quinine samples, the sample batch 05001022 stored in region A showed one tablet with more than twofold the allowed deviation. Three tablets (maximum two tablets) from sample batch 05004103 stored in region $\mathrm{C}_{2}$ were above the allowed deviation. The samples from the other regions complied with the standards on this test. The USP28-NF23 requirements for the quinine sulfate content in tablets are from $90 \%$ to $110 \%$ of the labeled amount, expressed as the sum of quinine sulfate and dihydroquinine sulfate. This specification was met by all samples. The samples from all regions also complied with USP28-NF23 requirements on the dissolution test: more than $75 \%$ of quinine sulfate dissolved in $45 \mathrm{~min}$. Six tablets were needed to comply with the test requirements for samples $\mathrm{A}, \mathrm{B}_{S S}, \mathrm{~B}_{1}, \mathrm{~B}_{2}, \mathrm{C}_{1}$, and $\mathrm{C}_{2}$, and 12 tablets for samples $\mathrm{D}_{S S}, \mathrm{D}_{1}$, and $\mathrm{D}_{2}$. No statistically significant difference $(p<0.05)$ was observed when the average drug release of the samples from all regions was compared with that of sample A for each batch.

A summary of the analytical results obtained with all samples is presented in Table 4.

TABLE 4 - Summary of the analytical results.

\begin{tabular}{|c|c|c|c|c|c|c|c|c|c|c|c|c|c|c|}
\hline \multirow[b]{3}{*}{ Product } & \multirow{3}{*}{$\begin{array}{c}\text { Visual } \\
\text { inspection }\end{array}$} & \multirow[b]{3}{*}{ ID } & \multirow{3}{*}{$\begin{array}{c}\text { Uniformity } \\
\text { of weight }\end{array}$} & \multirow{2}{*}{\multicolumn{3}{|c|}{ Physical tests }} & \multicolumn{2}{|c|}{ Dissolution (\%) } & \multirow{3}{*}{$\begin{array}{l}\text { Uniformity } \\
\text { of dosage } \\
\text { units }\end{array}$} & \multicolumn{4}{|c|}{ Assay (\% of labeled amount) } & \multirow{3}{*}{$\begin{array}{r}\text { Final } \\
\text { Result }\end{array}$} \\
\hline & & & & & & & \multirow{2}{*}{$\begin{array}{c}\text { lower } \\
\text { value } \\
\text { (sample) }\end{array}$} & \multirow{2}{*}{$\begin{array}{l}\text { higher } \\
\text { value } \\
\text { (sample) }\end{array}$} & & \multirow{2}{*}{$\begin{array}{c}\text { lower } \\
\text { value } \\
\text { (sample) }\end{array}$} & \multirow{2}{*}{$\begin{array}{c}\text { higher } \\
\text { value } \\
\text { (sample) }\end{array}$} & \multirow[b]{2}{*}{ Average } & \multirow[b]{2}{*}{ RSD } & \\
\hline & & & & hardness & friability & disintegration & & & & & & & & \\
\hline Chloroquine & + & + & + & + & + & + & $96.0\left(\mathrm{D}_{2}\right)$ & $99.2\left(B_{2}\right)$ & + & $98.3\left(C_{2}\right)$ & $102.6\left(B_{1}\right)$ & 99.9 & 1.35 & pass \\
\hline Mefloquine & - & + & + & + & + & + & $76.2\left(C_{1}\right)$ & $81.4(\mathrm{~A})$ & + & $93.6\left(D_{S S}\right)$ & $96.3\left(\mathrm{~B}_{2}\right)$ & 94.8 & 0.98 & fail \\
\hline Primaquine & - & + & + & + & + & + & $90.0\left(D_{S S}\right)$ & $95.4\left(C_{2}\right)$ & + & $93.9\left(\mathrm{C}_{2}\right)$ & $97.7(\mathrm{~A})$ & 95.7 & 1.16 & fail \\
\hline Quinine Batch 1022 & + & + & - & + & + & + & $85.4\left(\mathrm{D}_{\mathrm{SS}}\right)$ & $93.2(\mathrm{~A})$ & + & $92.3\left(\mathrm{~B}_{\mathrm{sS}}\right)$ & $94.4(\mathrm{~A})$ & 93.3 & 0.70 & fail \\
\hline Quinine Batch 4103 & + & + & - & + & + & + & $90.6(\mathrm{~A})$ & $91.8\left(\mathrm{C}_{1}\right)$ & + & $93.4\left(\mathrm{C}_{2}\right)$ & $94.2(\mathrm{~A})$ & 93.9 & 0.47 & fail \\
\hline
\end{tabular}

ID: identification test, +: complies with specifications, -: does not comply with specifications, RSD: relative standard deviation.

\section{DISCUSSION}

In reference to the $\mathrm{WHO}$ guidelines for the appropriate storage of medicines ${ }^{16}$, adequate drug storage conditions were found in the CENADI and in the state storeroom $\mathrm{C}_{\mathrm{SS}}$. Meanwhile, the state storerooms $\mathrm{B}_{S S}$ and $\mathrm{D}_{S S}$ need to improve their storage conditions, with $\mathrm{B}_{\mathrm{SS}}$ having a greater need for improvements.

For the state storerooms (Table 1), the relative humidity was not recorded because of the presence of air-conditioning, which is essential for adequate drug storage and to detect any equipment malfunction. Besides, the high temperatures and relative humidity observed in the north region state capitals B, C, and D (Table 3) reinforce the need to adequately control these parameters in their storerooms. A tracking system is necessary as well to withdraw drugs from the field and dispatch them to the health authorities in case of reported quality problems, avoiding their use by the population. The use of standard operational procedures must be encouraged in the state storerooms to equalize their practices on drug handling and proper storage. Finally, the access to drugs should be restricted to authorized personnel only, avoiding robbery and subsequent misemployment.
The storage conditions observed in the BHUs were inappropriate for antimalarials (Table 2). To provide instant treatment to infected patients, the BHUs keep an amount of drugs stored in cabinets or drawers, where they are not protected from the region's high temperature and humidity. However, the weekly drug delivery currently observed in the BHUs shortens the time in which antimalarials are kept in those places. Nevertheless, in areas with difficult access, such delivery might take within 6 months, occurring after the rainy season, thus exposing the drugs to excessive heat and humidity.

The study period was selected to mimic the local reality. The samples were delivered in June, before the beginning of the winter season, which is hotter and drier than the spring and summer seasons, which in turn are more humid and less warm. The ease and/or possibility of getting to all the regions selected to participate in this study was also considered. In the Brazilian Amazon, the rivers may not be navigable, and the wet dirt roads may not be adequate to drive on throughout the year.

The chloroquine samples generally exhibited no quality problems and were not affected by storage conditions, except for some humid packages and one blue-stained sample. The quality problems 
presented by samples of primaquine phosphate and quinine sulfate tablets (detached aluminum foil from the blister pack and tablet weight variations above the allowed limits, respectively) were attributed to packaging and manufacturing problems, and not to storage conditions as they also occurred in the samples stored in region $\mathrm{A}$. These tablet samples were found to be in good condition, as confirmed visually and by the physical-chemical analysis. The fact that they were manufactured recently, not long before their use in this study, might have contributed to their good quality.

The statistically significant difference in drug release found in mefloquine hydrochloride tablets may indicate a formulation problem or may be the result of inadequate storage conditions, as the region $B_{1}, C_{1}, C_{2}$, and $D_{1} B H U$ s have quite different storage conditions than the CENADI (region A). As mentioned, the simulated tropical conditions (high temperature and humidity) were capable of decreasing the drug release of tablets containing chloroquine and quinine in 3 months $s^{8-9}$. Similarly, decreased drug release was observed in mefloquine tablets under real tropical storage conditions, although to a lesser extent. We believe that this drug release reduction would not impair the expected therapeutic activity, as the rate did not fall below the allowed limits (70\% mefloquine hydrochloride release). This finding prompts further investigation of the influence of storage conditions on mefloquine hydrochloride drug release from tablets.

It is important to periodically evaluate the quality of essential drugs, mainly anti-infective ones, which, if substandard or counterfeit, pose a threat to patients and the public health, including the risk of selection of resistant parasites. The access to safe, effective, and good quality medicines is also a human rights issue. Along with quality, the storage conditions must be constantly evaluated and, if necessary, improved in order to allow the drugs to remain useful for their entire shelf life and avoid losses due to inadequate storage conditions.

The samples analyzed in our study, if made available to patients, would probably not contribute to resistant parasite selection, as all the dissolution and assay values were in agreement with specifications. The packaging deficiency in the primaquine samples is a serious problem that has to be addressed urgently to avoid tablet loss by the patients and to protect the drug from the environment's high humidity. The weight variation in the quinine samples is considered a minor problem; nevertheless, in a total quality management era, it is unacceptable to have nonattendances like these.

This work provided the Health Surveillance Secretary of the Brazilian Ministry of Health with useful information toward including drug quality in drug procurement policies. States and municipalities were also encouraged to improve their drug storage conditions.

\section{ACKNOWLEDGMENTS}

The authors would like to thank all the staff at the Secretaria de Vigilância em Saúde (Health Surveillance Secretary) of the Brazilian Ministry of Health for contributing to this study, and the state and municipal health secretaries for their readiness and support during the sample storage period. We also thank Prof. Cristina Duarte Vianna Soares for the English revision, critical analysis, and suggestions for improving this manuscript.

\section{CONFLICT OF INTEREST}

The authors declare that there is no conflict of interest.

\section{FINANCIAL SUPPORT}

This study was financially supported by the Pan American Health Organization (PAHO/OPS - RAVREDA/AMI), the United States Agency forInternationalDevelopment(USAID), theBrazilian Ministry of Health, the Brazilian Pharmacopeia, and the Brazilian National Council for Scientific and Technological Development (CNPq).

\section{REFERENCES}

1. Wongsrichanalai C, Pickard AL, Wernsdorfer WH, Meshnick SR. Epidemiology of drug resistant malaria. Lancet Infect Dis 2002; 2:209-218.

2. Minzi OMS, Moshi MJ, Hipolite D, Massele AY, Tomson G, Ericsson Ö, et al. Evaluation of the quality of amodiaquine and sulphadoxine/pyrimethamine tablets sold by private wholesale pharmacies in Dar Es Salaam Tanzania. J Clin Pharm Ther. 2003; 28:117-122.

3. Shakoor O, Taylor RB, Behrens RH. Assessment of the incidence of substandard drugs in developing countries. Trop Med Int Health 1997; 2:839-845.

4. Syhakhang L, Lundburg CS, Lindgren B, Tomson G. The quality of drugs in private pharmacies in Lao PDR: a repeat study in 1997 and 1999. Pharm World Sci 2004; 26:333-338

5. Taylor RB, Shakoor O, Behrens RH, Everard M, Low AS, Wangboonskul J, et al. Pharmacopoeial quality of drugs supplied by Nigerian pharmacies. Lancet 2001; 357:1933-1936.

6. Petralanda I. Quality of antimalarial drugs and resistance to Plasmodium vivax in the Amazonian region. Lancet 1995; 345:1433.

7. Newton PN, Green MD, Fernández FM, Day NPJ, White NJ. Counterfeit antiinfective drugs. Lancet Infect Dis 2006; 6:602-613.

8. Kayumba PC, Risha PG, Shewiyo D, Msami A, Masuki G, Ameye D, et al. The quality of essential antimicrobial and antimalarial drugs marketed in Rwanda and Tanzania: influence of tropical storage contidions on in vitro dissolution. J Clin Pharm Ther 2004; 29:331-338.

9. Risha PG, Shewiyo D, Msami A, Masuki G, Vergote G, Vervaet C, et al. In vitro evaluation of the quality of essential drugs on the Tanzanian market. Trop Med Int Health 2002; 7:701-707.

10. Ballereau F, Prazuck T, Schrive I, Lafleuriel MT, Rozec D, Fisch A, et al. Stability of essential drugs in the field: results of a study conducted over a two-year period in Burkina Faso. Am J Trop Med Hyg 1997; 57:31-36.

11. The United States Pharmacopeial Convention. United States Pharmacopeia. $28^{\text {th }}$ ed. Rockville (MD, USA): The United States Pharmacopeial Convention 2004.

12. Ministry of Health. Malaria Therapeutics Manual. Brasília (BR): National Health Foundation. Brazilian Ministry of Health; 2001.

13. Ministry of Health. National Malaria Control Program. Brasília (BR): Health Surveillance Secretary. Brazilian Ministry of Health; 2004.

14. Brazilian Pharmacopoeia Comission. Brazilian Pharmacopeia. $4^{\text {th }}$ ed. Part I. São Paulo (BR): CPRFB; 1988.

15. Rao AB, Murthy RSR. A rapid spectrophotometric method for the determination of mefloquine hydrochloride. J Pharm Biomed Anal 2002; 27:959-965.

16. Snow J. Guidelines for the storage of essential medicines and other health commodities [Internet]. World Health Organization; 2003. [cited 2011 March]. 114 p. Available from: http://www.who.int/entity/3by5/en/storage pocketguide.pdf. 